\title{
Isotopic composition of rainfall in Baja California Sur, México
}

\begin{abstract}
The study of the connection between precipitation and groundwater recharge/discharge using stable isotopes has been limited in México. One of the main limitations is the lack of local stable isotopes monitoring for rainfall. Indeed, only two stations of the Global Network of Isotopes in Precipitation operated in Mexico from 1962 to 1988. This study reports temporal characterization of stable isotopes in meteoric waters in the northwest of Mexico that has been lacking up to the present. Stable isotope analyses of the rain collected in the city of Loreto, state of Baja California Sur, from 2018 to 2021 were conducted using laser water isotope analyzers Picarro L2110-i and Los Gatos Research LWIA-45EP. A least squares regression of the isotope data was used to obtain the local meteoric water line: $\delta^{2} \mathrm{H}=8 \delta^{18} \mathrm{O}+9.4\left(\mathrm{r}^{2}=0.98\right)$. The average value of winter rain is $\delta^{18} \mathrm{O}=-2.46 \%$ and $\delta^{2} \mathrm{H}=$ $10.2 \%$, monsoon rain $\delta^{18} \mathrm{O}=-4.93 \%$ y $\delta^{2} \mathrm{H}=-30.3 \%$, atmospheric river rain $\delta^{18} \mathrm{O}=-5.35$ $\%$ and $\delta^{2} \mathrm{H}=-33.3 \%$ and tropical cyclones rain $\delta^{18} \mathrm{O}=-10.7 \%$ y $\delta^{2} \mathrm{H}=-76.3$. Isotope data indicated that tropical cyclones are the main source of recharge for the coastal aquifers of Baja California, Sur.
\end{abstract}

Keywords: Baja California Sur México, stable isotopes, rainfall, local meteoric water line, national network of isotopes in precipitation
Volume 5 Issue 3 - 2021

\author{
Luis González-Hita, Miguel Angel Mejía- \\ González, Blanca Carteño-Martinez, Juan \\ Carlos Aparicio-González, Dustin Mañón- \\ Flores \\ Department of Hydrology, Mexican Institute of Water \\ Technology, México
}

Correspondence: Miguel Angel Mejía-González, Mexican Institute of Water Technology, Paseo Cuauhnahuac 8532, Jiutepec, Morelos, México,

Emailmiguelangelmejiagonzalez@gmail.com, mamejia@tlaloc.imta.mx

Received: April 28, 2021 | Published: June 01, 2021
Abbreviations: GNIP, global network of isotopes in precipitation; IMTA, Mexican institute of water technology; RENIP, national network of isotopes in precipitation; NPSH, north pacific subtropical high; NAH, north American high; MM, Mexican monsoon; TS, tropical systems; ARs, atmospheric rivers; TC, tropical cyclones

\section{Introduction}

Several researchers have studied the contribution of different atmospheric mechanisms to the precipitation and groundwater recharge of the subtropical zones of Mexico. Rodgers ${ }^{1}$ reports that tropical cyclones (TC) contribute 30 to 40 percent of the rainfall of Baja California Sur. Jiang ${ }^{2}$ found that the maximum contribution of TC in the East-Central Pacific Basin occurs near the coast of Baja California Sur (about 55\%). Breña-Naranjo ${ }^{3}$ after analyzing rainfall data from 1998 to 2013, determined that TC contributes with 40\% of the total annual rainfall in Baja California Sur. According to García ${ }^{4}$ in Baja California Sur the monsoon produces $28.3 \%$ of the cloudiness.

Eastoe $^{5}$ analyzed the isotopic composition of coastal aquifers in Baja California Sur, finding that coastal groundwater has depleted values, which is not common at this latitude at sea level. Eastoe assumes it is because tropical cyclones are the main source of recharge for coastal aquifers. Ouyss ${ }^{6}$ carried out a study of the groundwater flow systems and their environmental interactions, in the protected area of Valle de Los Círios, Baja California. They found some groundwater samples with depleted heavy isotopes and low $\mathrm{Cl}$ content. They considered these results could be produced by modern recharge from tropical cyclones.

In order to characterize the spatial and temporal variability of the stable isotopes of precipitation on a global scale, the International Atomic Energy Agency and the World Meteorological Organization, implemented the Global Network of Isotopes in Precipitation (GNIP) ${ }^{7,8}$ The network began operating in 1960, collecting thousands of isotope and meteorological data to date. Only two GNIP stations operated in Mexico, one in the city of Chihuahua (north Mexico) and the other in the city of Veracruz (Gulf of Mexico) from 1962 to 1988. The study of the connection between precipitation and groundwater recharge/discharge using stable isotopes has been limited in México. One of the main limitations is the lack of local stable isotopes monitoring for rainfall.

In order to incorporate isotope hydrology into national water resources assessments, the Mexican Institute of Water Technology (IMTA) installed in 2018 a National Network of Isotopes in Precipitation (RENIP). This paper presents the stable isotopes of oxygen and hydrogen in precipitation, obtained from 2018 to 2021 in the rainwater collector installed in the coastal city of Loreto in the state of Baja California Sur. Results provide temporal characterization of stable isotopes in meteoric waters in the northwest of Mexico that has been lacking up to the present. This study may contribute to the understanding of groundwater recharge mechanisms in the arid subtropical regions of Mexico., ${ }^{910}$

\section{Study area}

The state of Baja California Sur is located in the northwest of Mexico, and limits to the north with Baja California $\left(28^{\circ} \mathrm{N}\right)$, to the east with the Gulf of California $\left(109^{\circ} \mathrm{W}\right)$, to the south $\left(23^{\circ} \mathrm{N}\right)$ and west $\left(115^{\circ} \mathrm{N}\right)$, with the Pacific Ocean ${ }^{11}$ (Figure 1). The state has a length of $750 \mathrm{~km}$, an average width of $100 \mathrm{~km}$ and 2,200 km of coastline. ${ }^{11}$ The entity is located within a high-pressure subtropical zone, with dry winds descending, which induce a dry and semiwarm to hot climate. ${ }^{11}$ The central desert is hot and dry, while the cape region has a hot, semi-arid steppe climate. Precipitation is very irregular in time and quantity, so almost all surface currents are intermittent. The average annual precipitation in the period 19412000 was $176 \mathrm{~mm}$, with the highest rainfall from July to January. ${ }^{12}$ The potential evaporation is approximately $1,500 \mathrm{~mm}$ per year. ${ }^{12}$ The most relevant physiographical characteristics are: the Vizcaino Desert in the northwest, the plain Llano de Magdalena in the west, and La Giganta range in the southeast. ${ }^{13}$ The mountains to the west are gently sloping and steep towards the Gulf. 

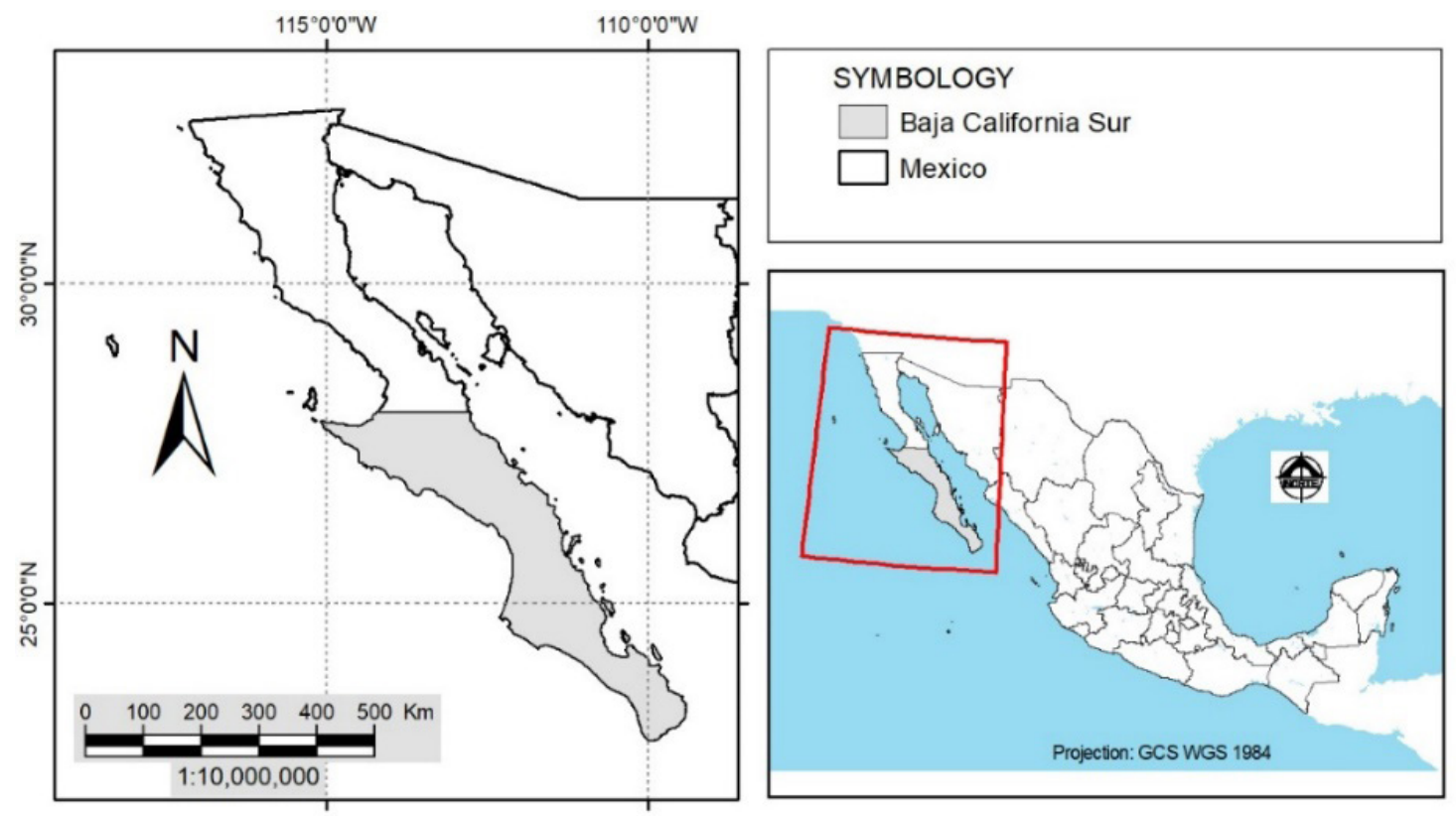

Figure I Study area.

Two geomorphological units are distinguished (1) coastal valleys and (2) mountain ranges. The valleys have flat shapes with slight slope to the sea, reduced dimensions and intermittent dense drainage, dendritic and subdendritic type in the mountains and parallel in the valleys. The coastal aquifers are unconfined, and consist of alluvial sediments deposited along the stream courses and on the coastal plain, with small dimensions and little storage capacity. ${ }^{14}$ Coastal aquifers are recharged by direct infiltration of rain over the valleys, as well as by infiltration of runoff in intermittent streams during the rains. The discharge occurs naturally by groundwater flow to the sea, and by evapotranspiration in small areas that have shallow water tables; artificially it is carried out by the extraction of water in dug and tube wells.

\section{Climatic and meteorological characteristics}

Among the climatic and meteorological components of the study area are: North pacific subtropical high (NPSH), North American high (NAH), Mexican monsoon (MM), cold fronts, atmospheric rivers and tropical systems (TS) (cyclones, storms and depressions). The NAH is a center of high atmospheric pressure $(1020 \mathrm{mb})$ produced in the winter by low temperatures, in the United States of North America and Canada. Masses of cold and dry air flow from the NAH, causing cold fronts in the region. ${ }^{15}$ Depending on the thermodynamic characteristics of the environment, the convergence of the cold fronts with lowlevel moisture advected from the eastern tropical pacific, produces moderate rain. The NPSH is a center of high atmospheric pressure $(\geq 1020 \mathrm{mb})$ in the pacific, located in winter around $28^{\circ} \mathrm{N}, 130^{\circ} \mathrm{W}$ and in summer at $38^{\circ} \mathrm{N}, 150^{\circ} \mathrm{W} .{ }^{16}$ The NPSH cause intense subsidence and atmospheric stability at those latitudes reducing deep convection, which prevents the formation of clouds. ${ }^{17}$

The movement of the NPSH to the north in the summer allows low-level winds transport moisture from the Pacific Ocean to Baja California Sur. ${ }^{18,19}$ The moisture warmed by the hot ground produces convective rain, also known as Monsoon rain. Atmospheric rivers (ARs) are long (thousands of kilometers) and narrow (hundreds of kilometers) regions where strong low-level winds transport water vapor across the midlatitudes. ${ }^{20} \mathrm{AR}$ are important source of precipitation in many regions, for instance, Dettinger ${ }^{21}$ estimated that $^{-}$ $25-50 \%$ of rainfall in California is produced by AR. The northeast Pacific is the region where the highest number of AR occurs. ${ }^{22}$

The movement of the NPSH to the north also allows that tropical cyclones (TC) approach to Baja California Sur, reducing atmospheric stability and causing ascending motion that produce deep convection and precipitation. ${ }^{17}$ Most of the TC of northeast pacific originate near the Mexican pacific coast, offshore of the Gulf of Tehuantepec. ${ }^{23}$ Many of the TC turn toward the northwest of México. The states of Baja California Sur and Sinaloa have the highest frequencies of TC touching land in México, both in the northwest. ${ }^{24}$

\section{Methodology}

Monthly precipitation samples were collected from June 2018 to January 2021 using a RS2 PALMEX ${ }^{25,26}$ rainwater collector (Figure 2) that allows monthly sampling without evaporation or isotopic fraction. Samples were filtered using cellulose membranes with 0.45 $\mu \mathrm{m}$ pore size, collected in $60 \mathrm{~mL}$ high-density polyethylene bottles with conic and polyseal inserts, and filled with no headspace when permitted. The collector is located at the facilities of the Loreto National Meteorological Service, CONAGUA, whose coordinates are $(26.011 \mathrm{~N}, 111.35 \mathrm{~W})$ and altitude of $6 \mathrm{~m}$ above sea level. Rainfall amounts were measured using a Data-Logging Rain Gauge, WatchDog 1120 .

Stable isotope analyses were conducted at the Isotope Hydrology Laboratory of the Mexican Institute of Water Technology (IMTA), using laser water isotope analyzers Picarro L2110-i and Los Gatos Research LWIA-45EP. The analytical precision was $\pm 0.5 \%$ for $\delta^{2} \mathrm{H}$ and $\pm 0.13 \%$ for $\delta^{18} \mathrm{O}$. The secondary standards were: Popocatepetl Volcano Water, PVW $\left(\delta^{2} \mathrm{H}=-81.4 \%\right.$ o, $\left.\delta^{18} \mathrm{O}=-11.79 \%\right)$, Laguna Verde Water, LVW $\left(\delta^{2} \mathrm{H}=17.1 \%\right.$, $\delta^{18} \mathrm{O}=3.38 \%$ ), and Playa del Carmen Well Water, PCWW $\left(\delta^{2} \mathrm{H}=-28 \%, \delta^{18} \mathrm{O}=-4.8 \%\right)$. PVW and LVW standards were used to normalize the results to the VSMOW2-SLAP2 scale, while PCWW was used as quality control and drift control standard. 


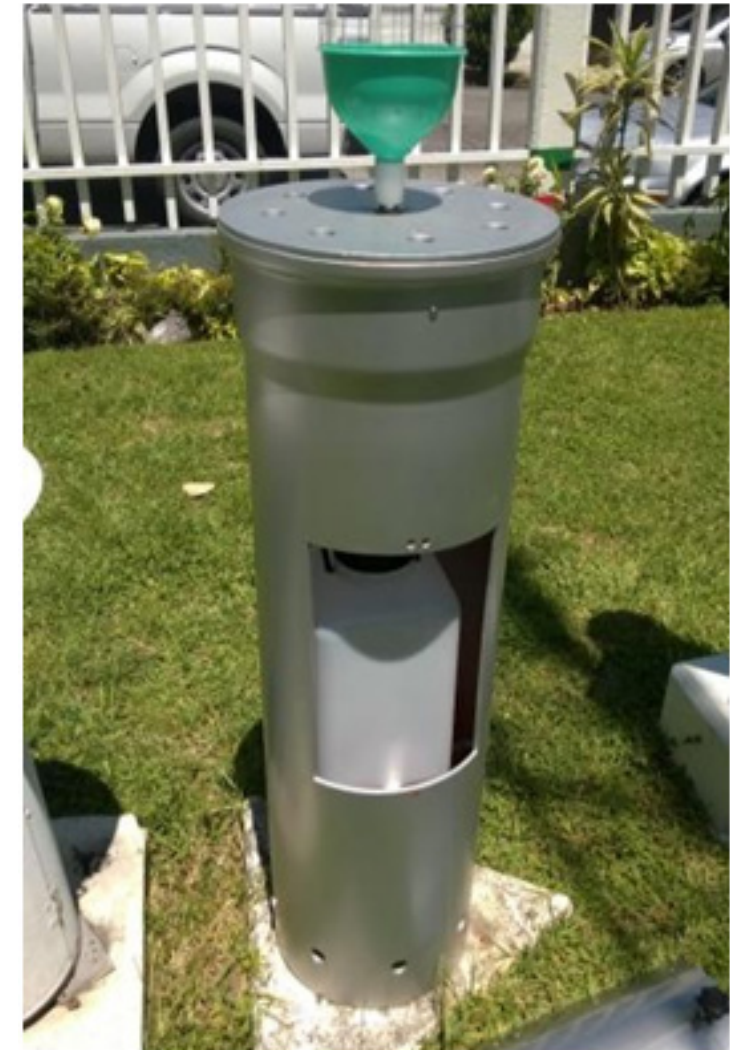

Figure 2 Rainwater collector RS2 PALMEX.

\section{Results and discussion}

\section{Rainfall}

The accumulated monthly rainfall samples from 2018 to 2021 used in this study were analyzed to determine their content of stable isotopes. The values of the $\delta^{18} \mathrm{O} \%$ (VSMOW) and $\delta^{2} \mathrm{H} \%$ (VSMOW) are shown in Table 1. With the data, the graph of the relationship $\delta^{18} \mathrm{O}$ $\%$ (VSMOW) versus $\delta^{2} \mathrm{H} \%$ (VSMOW) was elaborated (Figure 3). A least squares regression of the precipitation isotope data was used to obtain the local meteoric water line:

$\delta^{2} \mathrm{H}=8 \delta^{18} \mathrm{O}+9.4\left(\mathrm{r}^{2}=0.98\right)$. The average value of winter rain is $\delta^{18} \mathrm{O}=-$ $2.46 \%$ and $\delta^{2} \mathrm{H}=-10.2 \%$, monsoon rain $\delta^{18} \mathrm{O}=-4.93 \%$ y $\delta^{2} \mathrm{H}=-30.3$ $\%$, atmospheric river rain $\delta^{18} \mathrm{O}=-5.35 \%$ and $\delta^{2} \mathrm{H}=-33.3 \%$ and tropical cyclones rain $\delta^{18} \mathrm{O}=-10.7 \%$ y $\delta^{2} \mathrm{H}=-76.3 \%$ (Figure 4).

The depleted heavy isotope values (more negative) correspond to tropical systems rain (cyclones, storms, and depressions). The enriched heavy isotope values (less negative) correspond to winter rain.

\section{Winter rainfall}

The cold fronts season in Mexico begins in September and ends in May of the following year. ${ }^{27}$ In the period 1981-2010 there were an average of 44 frontal systems during this season. ${ }^{27}$ Moisture transport in the American continent, during winter, has a westward flow in the tropics and eastward in the middle latitudes. ${ }^{28}$ During this season, there is a moisture flux from the Pacific Ocean towards the northwest of Mexico. ${ }^{28}$ Depending on the thermodynamic characteristics of the environment, the convergence of the cold fronts with moisture advected from the Pacific Ocean, produces moderate rain.

Table I Stable isotopes of oxygen and hydrogen of precipitation in Loreto

\begin{tabular}{|c|c|c|c|c|c|c|c|c|}
\hline Collector & Latitude & Longitude & Altitude & $\begin{array}{l}\text { Sampling } \\
\text { date }\end{array}$ & $\begin{array}{l}\delta^{18} O(\% \circ) \\
\text { VSMOW }\end{array}$ & $\begin{array}{l}\delta^{2} \mathrm{H}(\% \circ) \\
\text { VSMOW }\end{array}$ & $\begin{array}{l}\text { Precipitation } \\
(\mathrm{mm})\end{array}$ & Rain system \\
\hline Loreto & 26.012 & -111.349 & 6 & Jun-18 & -13.48 & -97.8 & 33.9 & Hurricane Bud \\
\hline Loreto & 26.012 & -111.349 & 6 & Sep- 18 & -12.13 & -86.9 & 52 & $\begin{array}{l}\text { Tropical depression } \\
\text { Nineteen-E }\end{array}$ \\
\hline Loreto & 26.012 & -111.349 & 6 & Jan-19 & -2.38 & -6.9 & 13.7 & Winter rain \\
\hline Loreto & 26.012 & -111.349 & 6 & Aug-19 & -5.74 & -34.7 & 89.9 & Monsoon rain \\
\hline Loreto & 26.012 & -111.349 & 6 & Sep-19 & -9.43 & -60.8 & 30.2 & Hurricane Lorena \\
\hline Loreto & 26.012 & -111.349 & 6 & Oct-19 & -10.63 & -80.9 & 36 & $\begin{array}{l}\text { Tropical depression } \\
\text { Invest } 96 \mathrm{E}\end{array}$ \\
\hline Loreto & 26.012 & -111.349 & 6 & Nov-19 & -7.74 & -55 & 86.4 & Tropical storm Raymond \\
\hline Loreto & 26.012 & -111.349 & 6 & Dec-19 & -1.98 & -0.7 & 1.4 & Winter rain \\
\hline Loreto & 26.012 & -111.349 & 6 & Mar-20 & -2.23 & -13.9 & 5.2 & Winter rain \\
\hline Loreto & 26.012 & -111.349 & 6 & Aug-20 & -4.11 & -25.9 & 4.8 & Monsoon rain \\
\hline Loreto & 26.012 & -111.349 & 6 & Sep-20 & -3.26 & -19.1 & 11.32 & Winter rain \\
\hline Loreto & 26.012 & -111.349 & 6 & Jan-2I & -5.35 & -33.3 & 8.38 & Atmospheric river \\
\hline
\end{tabular}




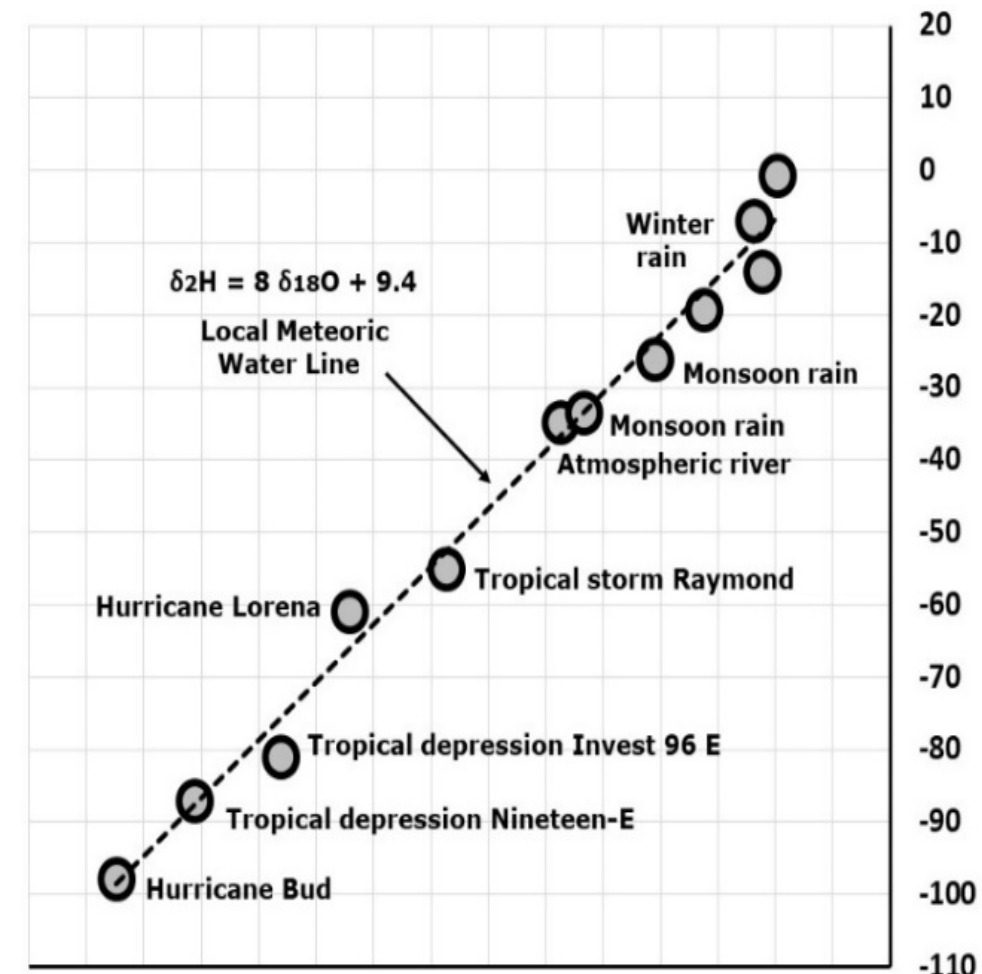

$\begin{array}{llllllllllllllll}-15 & -14 & -13 & -12 & -11 & -10 & -9 & -8 & -7 & -6 & -5 & -4 & -3 & -2 & -1 & 0\end{array}$

\section{$\delta^{18} 0(\%)$ VSMOW}

Figure 3 Relationship between $\delta^{18} \mathrm{O}$ and $\delta^{2} \mathrm{H}$ in precipitation of Loreto, and local meteoric water line.

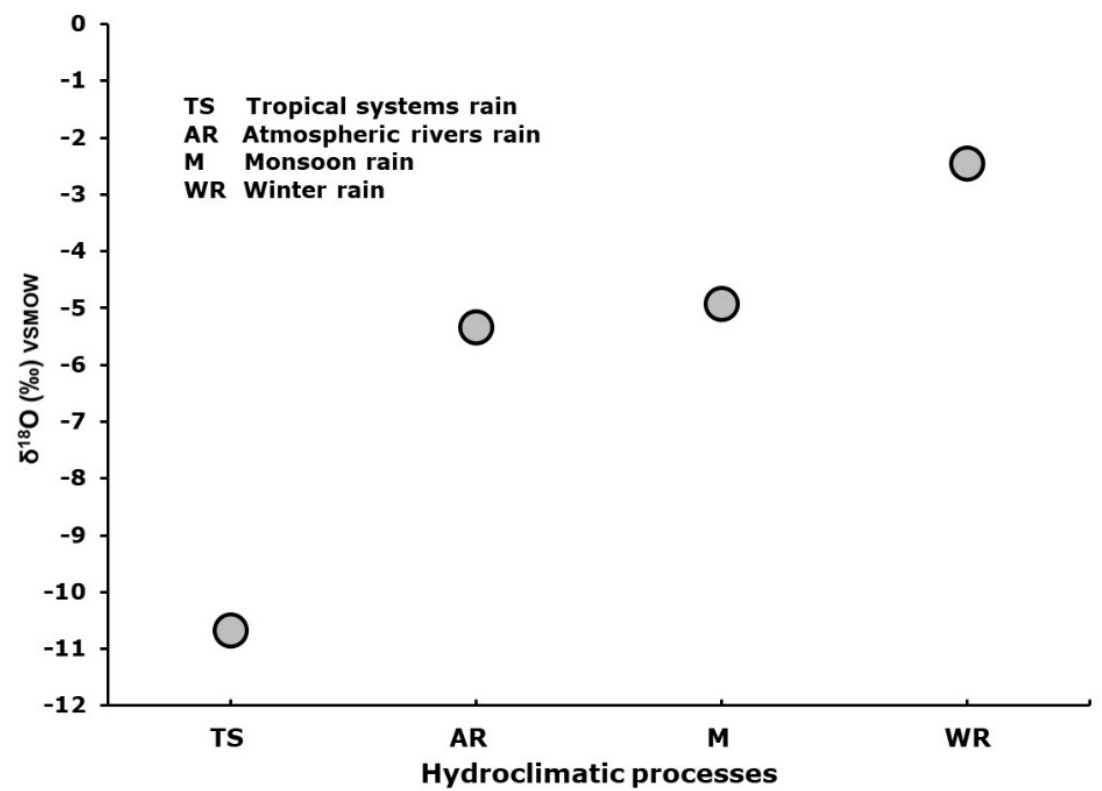

Figure 4 Average value of $\delta^{18} \mathrm{O}$ of winter rain, monsoon rain, atmospheric rivers rain, and tropical systems rain (cyclones, storms and depressions).

On January 6 and 7, 2019, the convergence of a cold front with moisture from the Pacific Ocean (Figure 5), caused rains in the Loreto area. ${ }^{29}$ According to the daily rain report of Loreto $^{30}$ in the month of January 2019, it only rained on the 6 th and $7^{\text {th }}$, therefore the accumulated monthly rain in the collector for this month corresponds to winter rain. In December 2019, the entry of a cold maritime air mass through the northwest of Baja California and a cold continental air mass that descended from the center of the United States, in combination with entry of moisture from the Pacific Ocean associated with a subtropical jet stream, caused rains in Baja California Sur. ${ }^{29}$ Winter precipitation in Baja California Sur is enriched in heavy isotopes, because represents the early stage of rainout with minimal evolution from the Pacific Ocean. ${ }^{31}$ 


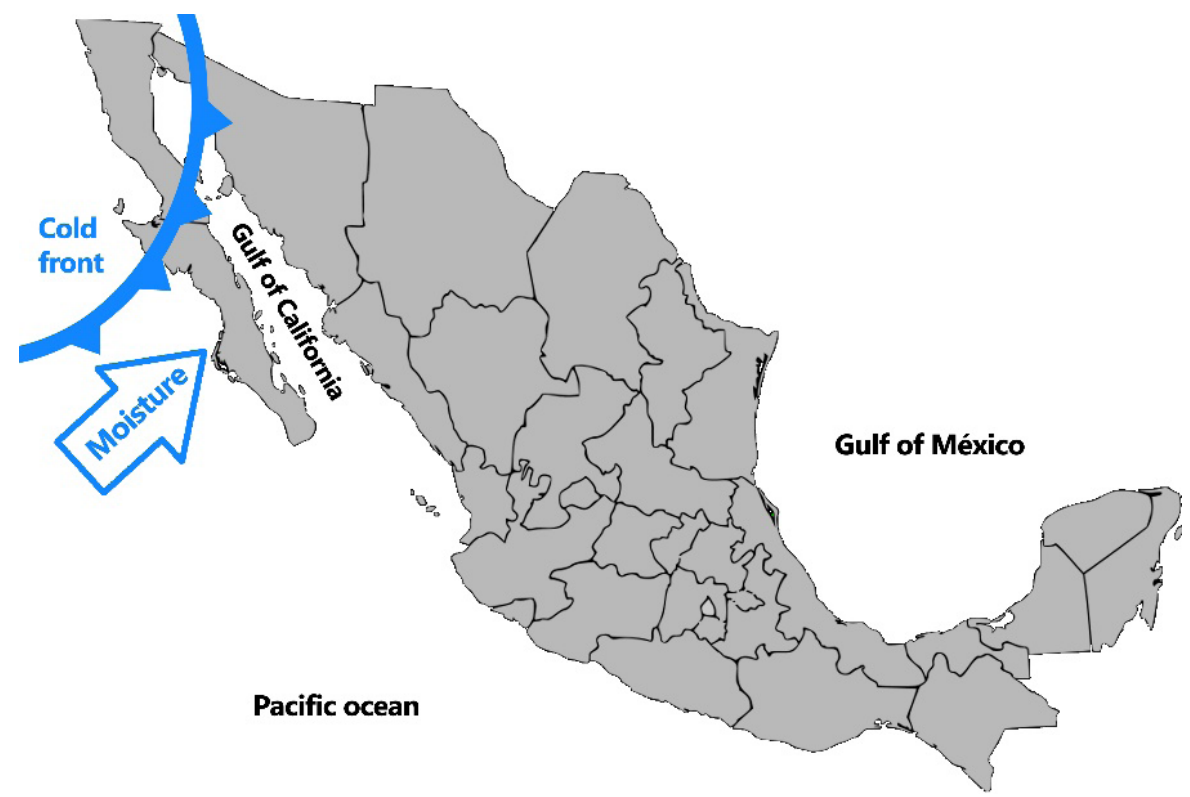

Figure 5 Weather systems on January 6, 2019 in Baja California Sur. ${ }^{29}$

\section{Tropical cyclone rain}

In the area, during the study period, various tropical cyclone systems were present. One of them was hurricane Bud that formed on June 9 off the coast of Guerrero, and moved westward in a parallel trajectory to the coasts of Guerrero, Michoacán and Jalisco, making landfall in Baja California Sur on June $15^{32}$ (Figure 6). According to the daily rain report of Loreto $^{33}$ in the month of June 2018, it only rained on the $15^{\text {th }}$ and $16^{\text {th }}$, therefore the accumulated monthly rain in the collector for this month corresponds to tropical cyclone rain. Another event corresponded to hurricane Lorena that affected the Mexican Pacific coast during the second half of September 2019. ${ }^{34}$ It began as a zone of instability in the state of Chiapas on the $14^{\text {th }}$. It reached the category of a tropical storm on the $17^{\text {th }}$ when it was located in Guerrero, and category of hurricane when it arrived in Colima. It made landfall on September 19 in Jalisco. On September 20, the hurricane made landfall in Baja California Sur with winds of $130 \mathrm{~km} / \mathrm{h}$ and a minimum pressure of $986 \mathrm{mb}$ (Figure 7). According to the daily rain report of Loreto ${ }^{30}$ in the month of September 2019, it only rained on the 20th and $21^{\text {st }}$, therefore the accumulated monthly rain in the collector for this month corresponds to tropical cyclone rain. Tropical cyclones produce rain with depleted heavy isotopes due to fractionation in massive precipitating clouds. ${ }^{35,36}$ During horizontal transport of vapor from the outer edge of the rainshield to the eyewall, and later vertical transport to great heights, condensation and precipitation occur, decreasing the values of $\delta^{18} \mathrm{O}$ and $\delta^{2} \mathrm{H}$ due to progressive removal of heavy isotopes..$^{35,37,38,39}$

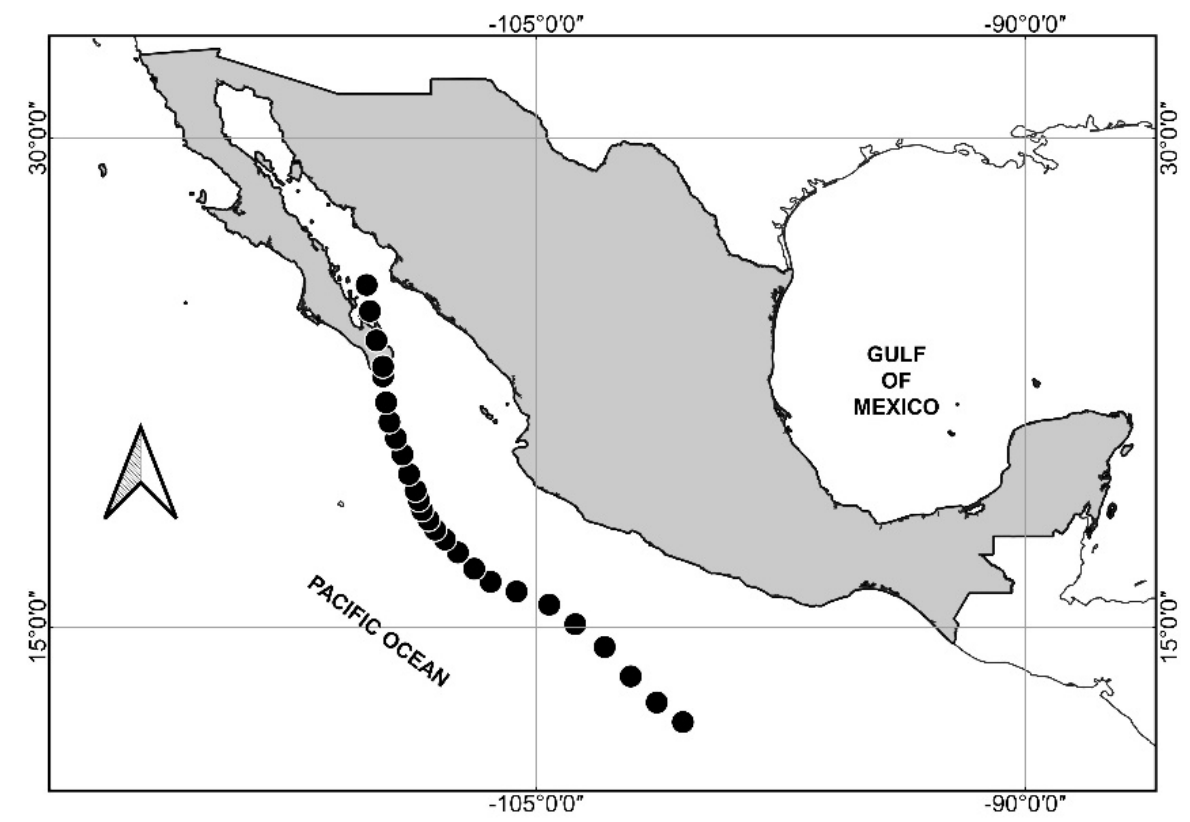

Figure 6 Hurricane Bud, positions 9-15 June 2018.

(Data retrieved from https://https://www.nhc.noaa.gov/data/tcr/EP032018_Bud.pdf) 


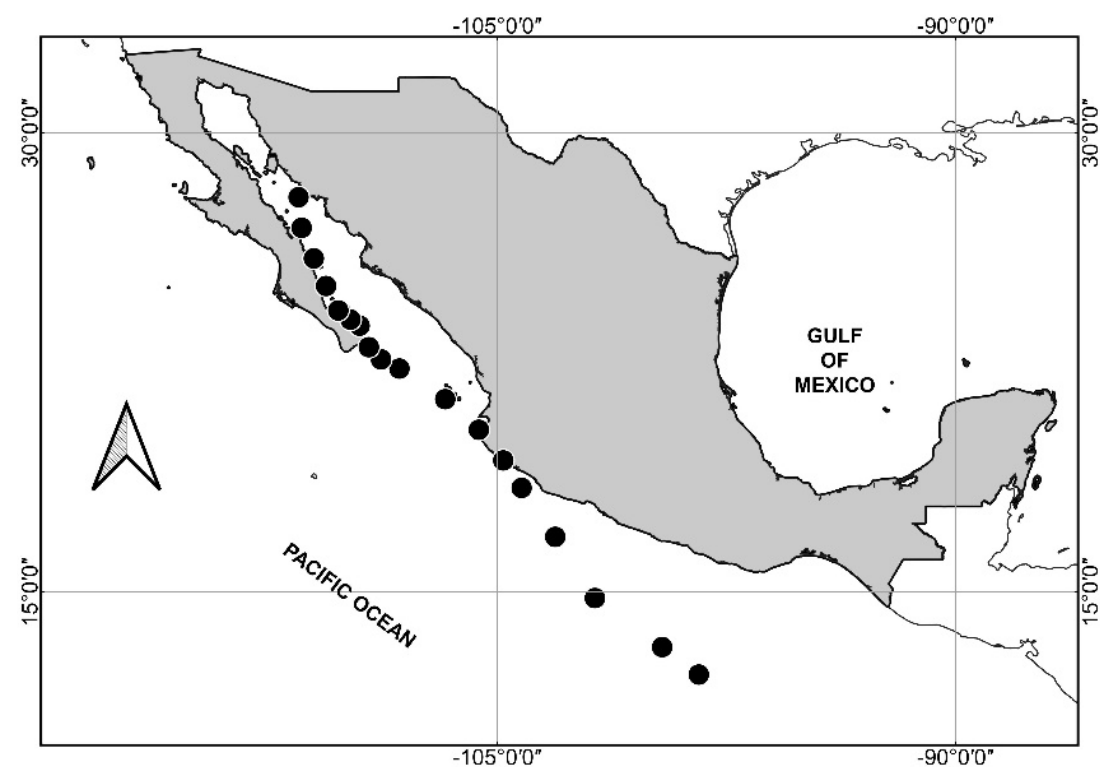

Figure 7 Hurricane Lorena, positions 17-22 September 2019.

(Data retrieved from https://www.nhc.noaa.gov/data/tcr/EPI520I9_Lorena.pdf)

\section{Monsoon rain}

In the summer, the air over the continent warms up more than the air over the ocean, producing a pressure gradient between the continent (low pressure) and the Pacific Ocean (high pressure). The barometric gradient induces wind currents that transport moisture from the Pacific Ocean to the continent. ${ }^{40}$ Intense warming of the Sonora Desert during the summer, produces a thermal gradient between the sea surface in the Gulf of California $\left(30^{\circ} \mathrm{C}\right)$ and the Pacific Ocean $\left(22^{\circ} \mathrm{C}\right) .^{41}$ The thermal gradient is associated with an atmospheric pressure gradient between the Pacific Ocean $(1012 \mathrm{hPa})$ and the Gulf of California $(1008 \mathrm{hPa}) .^{41}$ The pressure gradient induces moisture transport from the Pacific Ocean to the Gulf of California.

The moisture warmed by the hot ground is lifted in a strong upward air motion to high altitudes. ${ }^{42}$ Convective updrafts are supply with parental moisture enriched in heavy isotopes from the Pacific
Ocean. After condensation, raindrops fall in a strong downward air motion. ${ }^{42}$ The high falling speed of the raindrops ${ }^{43}$ does not allow isotopic exchange with surrounding moisture ${ }^{44,45}$ preserving the heavy isotopes acquired during the updraft.

\section{Atmospheric rivers rain}

At the convergence zone of the cold front and the warm conveyor belt of extratropical cyclones, high vertically integrated water vapour bands are formed ${ }^{46}$ The moisture bands, known as Atmospheric Rivers (ARs) are long (thousands of kilometers) and narrow (hundreds of kilometers) corridors. ${ }^{47}$ When the moisture of the ARs interact with cold fronts in Baja California Sur, produces precipitation with heavy isotope ratio due to incipient rainout. The interaction of moisture of an atmospheric river with a cold front, in January 2021, produced rains in the northwest of the Mexican Republic ${ }^{48}$ (Figure 8).

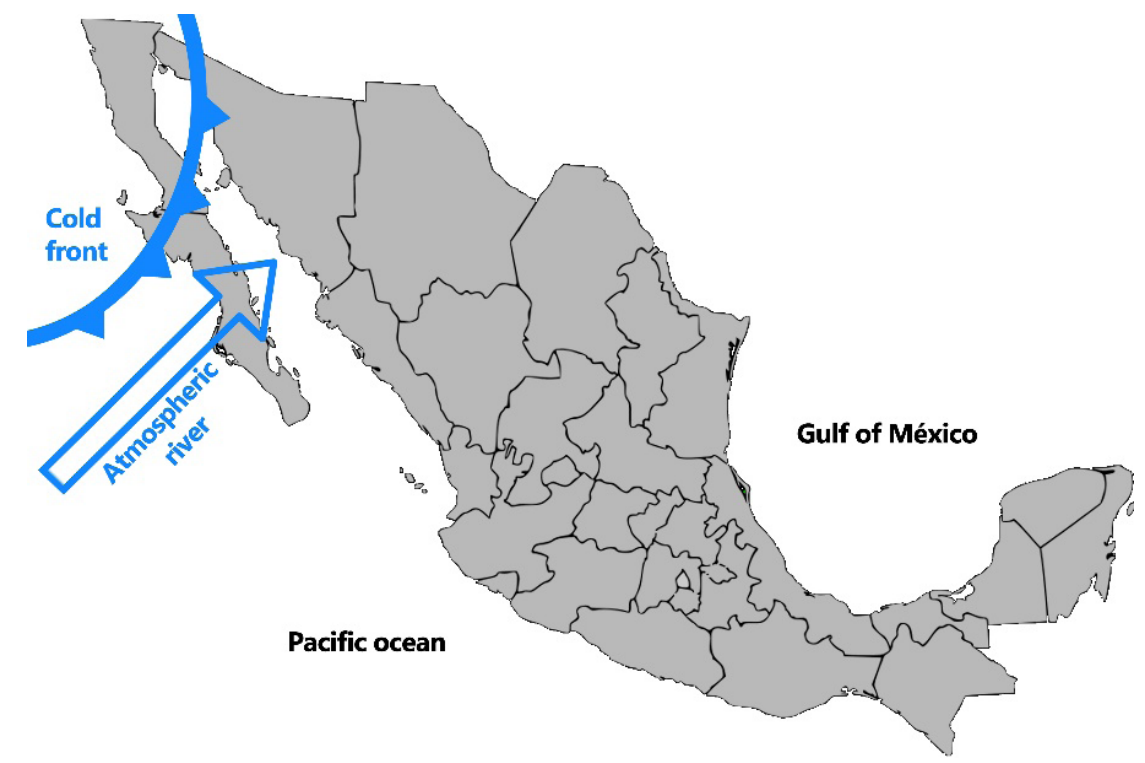

Figure 8 Weather systems on January 21, 202I in Baja California Sur. ${ }^{48}$ 


\section{Groundwater}

Wassenaar ${ }^{49}$ and Eastoe ${ }^{50}$ determined the stable isotopes of oxygen and hydrogen of groundwater in various coastal aquifers of Baja California Sur (Todos Santos, Santiago, Plutarco Elías, Santa Rita and Santo Domingo). They found that coastal groundwater has depleted heavy isotopes, which is not common of aquifers close to the sea.
Eastoe assumes it is because tropical cyclones are the main source of groundwater recharge. According to the data obtained in this study, the isotopic composition of tropical systems rain (cyclones, storms and depressions) is similar to the isotopic composition of coastal groundwater (Figure 9). This would indicate that tropical systems are the main source of recharge for the coastal aquifers of Baja California Sur, México.

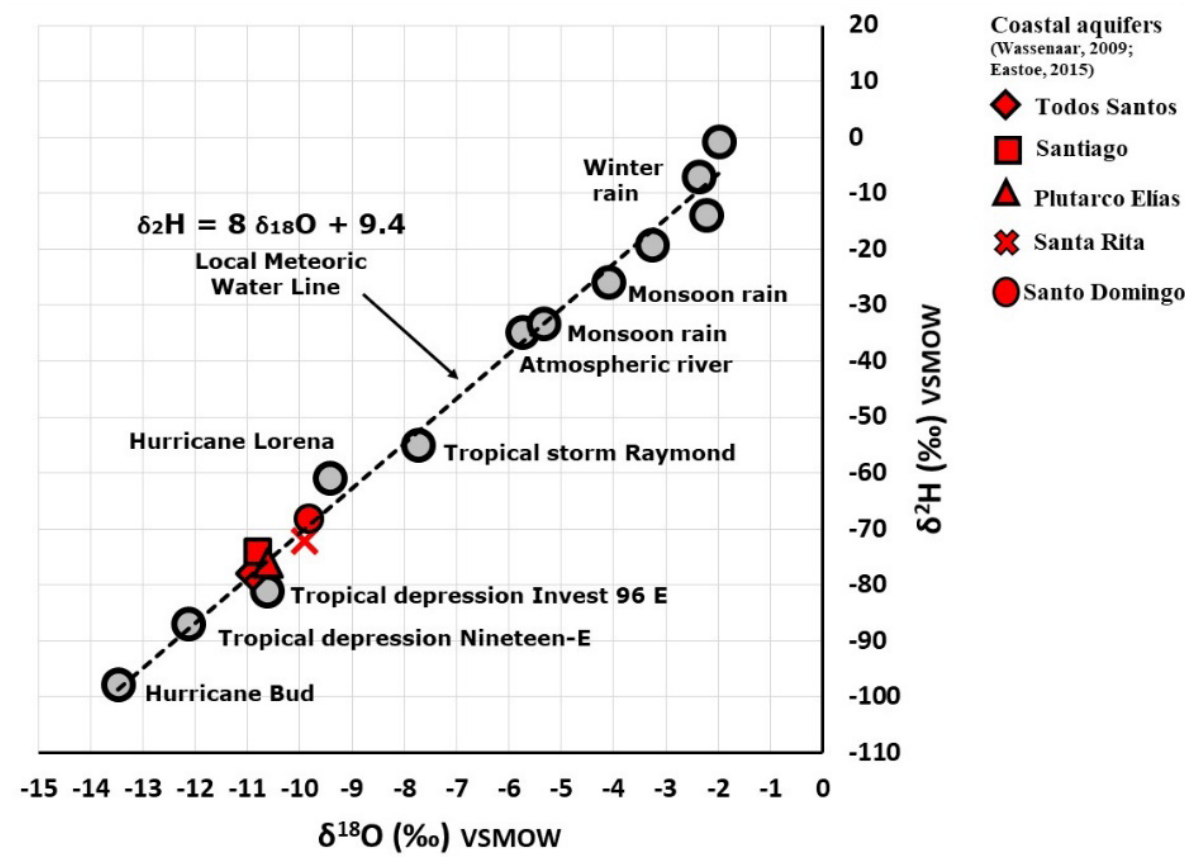

Figure 9 Isotopic composition of rainfall and coastal groundwater in Baja California Sur, México.

\section{Conclusion}

This study presents the temporal characterization of stable isotopes in meteoric waters in the northwest of Mexico, during 2018 to 2021. In this arid region, with scarcity of long-term groundwater and precipitation monitoring, isotopic assessments could help to determine the origin, period, and areas of effective recharge of groundwater resources, which would be useful information for their sustainable use, protection, and administration. The results revealed a temporal pattern in the isotope composition of precipitation, with enriched isotopic composition during the winter season, and depleted during the cyclones season. Four hydroclimatic processes were identified as determining the local meteoric water line: tropical systems (cyclones, storms and depressions), atmospheric rivers, monsoon systems and cold fronts. Likewise, stable isotope data indicated that tropical cyclones are the main source of recharge for the coastal aquifers of Baja California, Sur. Climate models and observed trends suggest that warmed climate will drive latitudinal redistribution of precipitation, decreasing rainfall at subtropical latitudes..$^{51,52,53}$ Information of the currently rainfall isotope data could be useful as a baseline to evaluate future changes of the precipitation and groundwater recharge.

\section{Acknowledgments}

The data used in this work were generated in the National Network of Isotopes in Precipitation in Mexico (RENIP), operated by the Mexican Institute of Water Technology, with the collaboration of the National Meteorological Service of CONAGUA, The Water System of Mexico City, and The International Atomic Energy Agency.

\section{Conflicts of interest}

The authors declare that no conflict of interests is present in this study.

\section{References}

1. Rodgers EB, Adler RF, Pierce HF. Contribution of tropical cyclones to the North Pacific climatological rainfall as observed from satellites. Journal of Applied Meteorology. 2000;39:1658-1678.

2. Jiang H, Zipser EJ. Contribution of Tropical Cyclones to the Global Precipitation from Eight Seasons of TRMM Data: Regional, Seasonal, and Interannual Variations. Journal of Climate. 2010;23(6):1526-1543.

3. Breña-Naranjo JA, Pedrozo-Acuña A, Pozos-Estrada O, et al. The contribution of tropical cyclones to rainfall in Mexico. Physics and Chemistry of the Earth. 2015;83-84:111-122.

4. García E, Trejo RI. La presencia del Monzón en el Noroeste de México. Investigaciones Geográficas. 1994;28.

5. Eastoe C, Hess G, Mahieux S. Identifying Recharge from Tropical Cyclonic Storms, Baja California Sur, México. Groundwater. 2015;53:133-138.

6. Ouysse S, Wehncke EV, Rivera JJC. Investigating regional groundwater flow systems in Baja California central desert region. Int J Hydro. 2018;2(1):83-93.

7. Schotterer U, Oldfield F, Froehlich K. GNIP Global Network for Isotopes in Precipitation. Switzerland: Laederach AG. 1996.

8. GNIP (Global Network of Isotopes in Precipitation). 2012. 
9. Sánchez-Murillo R, Birkel C. Groundwater recharge mechanisms inferred from isoscapes in a complex tropical mountainous region. Geophys Res Lett. 2016;43:5060-5069.

10. Sánchez-Murillo R, Esquivel-Hernández G, Sáenz-Rosales O, et al. Isotopic composition in precipitation and groundwater in the northern mountainous region of the Central Valley of Costa Rica. Isotopes in Environmental and Health Studies. 2017;53:1-17.

11. INEGI. Síntesis Geográfica del Estado de Baja California Sur. ISBN 97013-0097-1; 1995. p. 1-35.

12. COMISIÓN NACIONAL DEL AGUA. Compendio Básico del Agua en México 2002 ISBN 968-817-506-4; 2002.

13. Sirkin L, Pedrín-Aviles S, Padilla-Arredondo G. Holocene vegetation and climate of Baja California Sur, México. Revista Mexicana de Ciencias Geológicas. 1994;11(1).

14. Comisión Nacional Del AGUA. Actualización de la disponibilidad media anual de agua en el acuífero Todos Santos Baja California Sur; 2015.

15. Garreaud R. Subtropical cold surges: Regional aspects and global distribution. International Journal of Climatology. 2001;21:1181-1197.

16. Huyer A. Coastal upwelling in the California current system. Progress in Oceanography. 1983;12(3):259-284.

17. Domínguez C, Magaña V. The Role of Tropical Cyclones in Precipitation Over the Tropical and Subtropical North America. Front. Earth Sci. 2018.

18. Hales JE. Surges of maritime tropical air northward over the Gulf of California. Monthly Weather Review. 1972;100:298-306.

19. Douglas MW, Maddox RA, Howard K, et al. The Mexican Monsoon Journal of Climate. 1993;6(8):1665-1677.

20. Gimeno L, Nieto R, Vázquez M, et al. Atmospheric Rivers: a mini-review. Frontiers in Earth Science. 2014;2:2.

21. Dettinger MD, Ralph FM, Das T, et al. Atmospheric Rivers, Floods and the Water Resources of California. Water. 2011;3:445-478.

22. Waliser DE, Moncrieff MW, Burridge D, et al. The year of tropical convection (May 2008-April 2010): Climate variability and weather highlights. Bull Amer Meteor. Soc. 2012;93:1189-1218.

23. Romero-Vadillo E, Zaytsev O, Morales-Pérez R. Tropical cyclone statistics in the Northeastern Pacific. Atmósfera. 2007;20(2):197-213.

24. Farfán LM, Alfaro EJ, Cavazos T. Characteristics of tropical cyclones making landfall on the Pacific coast of Mexico: 1970-2010. Atmósfera. 2013;26(2):163-182.

25. Gröning M, Lutz HO, Roller-Lutz Z, et al. A simple rain collector preventing water re-evaporation dedicated for $\delta^{18} \mathrm{O}$ and $\delta^{2} \mathrm{H}$ analysis of cumulative precipitation samples. Journal of Hydrology. 2012;448449:195-200.

26. IAEA. A new device for montly rainfall sampling for GNIP. Water and Environment Newsletter, International Atomic Energy Agency. Special Issue on the Global Network of Isotopes in Precipitation. 2002;16:5.

27. SERVICIO METEOROLOGICO NACIONAL. Weather report in Mexico. 2019.

28. Trenberth KE, Guillemot CJ. Evaluation of the atmospheric moisture and hydrological cycle in the NCEP/NCAR reanalyses. Climate Dynamics. 1998;14:213-231.

29. SERVICIO METEOROLOGICO NACIONAL. Weather report in Mexico. 2019.

30. CONAGUA-DLBCS. Daily rain report in Baja California Sur. 2019.

31. Clark ID, Fritz P. Environmental Isotopes in Hydrogeology. CRC Press, New York. 1997.
32. SERVICIO METEOROLOGICO NACIONAL. Weather report in Mexico. 2018

33. CONAGUA-DLBCS. Daily rain report in Baja California Sur. 2018.

34. SERVICIO METEOROLOGICO NACIONAL. Weather report in Mexico. 2019.

35. Gedzelman S, Lawrence J, Gamache J, et al. Probing Hurricanes with Stable Isotopes of Rain and Water Vapor. Monthly Weather Review. 2003;131:1112-1127.

36. Good SP, Mallia DV, Lin JC, et al. Stable Isotope Analysis of Precipitation Samples Obtained via Crowdsourcing Reveals the Spatiotemporal Evolution of Superstorm Sandy. PLOS ONE. 2014;9(3):e91117.

37. Bony S, Risi C, Vimeux F. Influence of convective processes on the isotopic composition $\left(\delta^{18} \mathrm{O}\right.$ and $\left.\delta \mathrm{D}\right)$ of precipitation and water vapor in the tropics: 1. Radiative-convective equilibrium and Tropical OceanGlobal Atmosphere-Coupled Ocean-Atmosphere Response Experiment (TOGA-COARE) simulation. Journal of Geophysical Research. 2008;113:ID19305.

38. Scholl MA, Shanley JB, Zegarra JP, et al. The stable isotope amount effect: New insights from NEXRAD echo tops, Luquillo Mountains, Puerto Rico. Water Resources Research. 2009;45:W12407.

39. Scholl MA, Murphy SF. Precipitation isotopes link regional climate patterns to water supply in a tropical mountain forest, eastern Puerto Rico. Water Resources Research. 2014;50(5):4305-4322.

40. García E, Trejo RI. La presencia del Monzón en el Noroeste de México. Investigaciones Geográficas. 1994;28.

41. Morales-Acuña E, Torres CR, Linero-Cueto JR. Surface wind characteristics over Baja California Peninsula during summer. Regional studies in Marine Sciences. 2019;29:100654.

42. Aggarwal P, Romatschke U, Araguas-Araguas L, et al. Proportions of convective and stratiform precipitation revealed in water isotope ratios. Nature Geoscience. 2016;9:624-629.

43. Houze RA. Cloud dynamics. International Geophysics Series. 2014; $104: 275$.

44. Bolin, B. On the use of tritium as a tracer for water in nature. Proc. Second United Nations Intl. Conf. Peaceful Uses of Atomic Energy. 1959;8:336343

45. Knight CA. Radial and tangential variation of deuterium in hailstones. Jour Atmos Sci. 1975;311(32):990-2000.

46. Bao JW, Michelson SA, Neiman PJ, et al. Interpretation of enhanced integrated water vapor bands associated with extra-tropical cyclones: their formation and connection to tropical moisture. Mon Wea Rev. 2006;134:1063-1080.

47. Gimeno L, Nieto R, Vázquez M. Atmospheric Rivers: a mini-review. Frontiers in Earth Science. 2014;2:2.

48. Servicio Meteorologico Nacional. Weather report in Mexico. 2021.

49. Wassenaar LI, VanWilgenburg SL, Larson K, et al. A groundwater isoscape $(\delta \mathrm{D}, \delta 180)$ for Mexico. Journal of Geochemical Exploration. 2009;102(3):123-136

50. Eastoe C, Hess G, Mahieux S. Identifying Recharge from Tropical Cyclonic Storms, Baja California Sur, Mexico. Groundwater. 2015;53:133-138.

51. Zhang X, Zwiers F, Hegerl G, et al. Detection of human influence on twentieth-century precipitation trends. Nature. 2007;448:461-465.

52. Held IM, Soden BJ. Robust responses of the hydrological cycle to global warming. J Clim. 2006;19:5686-5699.

53. Emori S, Brown SJ. Dynamic and thermodynamic changes in mean and extreme precipitation under changed climate. Geophys Res Lett. 2005;32:L17706. 